\title{
Induction of systemic and mucosal immune response in mice immunised with porins of Salmonella typhi
}

\author{
MANTEJ SINGH, HARPREET VOHRA, LATA KUMAR* and NIRMAL K. GANGULY* \\ Departments of Paediatrics and *Experimental Medicine and Biotechnology, Postgraduate Institute of Medical \\ Education and Research, Chandigarh, India
}

\begin{abstract}
Porins, purified from Salmonella typhi strain 0901 provided $90 \%$ protection to BALB/c mice against a lethal dose $(300 \times \mathrm{LD50})$ of $S$. typhi Ty 2 when given intraperitoneally. To measure the porin-induced cellular immune responses, macrophages and lymphocytes were isolated from spleen and lamina propria (LP) of porin immunised-challenge mice and of infected and control mice; T-cell phenotypes, lymphocyte proliferation and cytokine production were studied. The secretory IgA (sIgA) antibody level in the intestinal fluid was also measured to study mucosal immune response. After immunisation, the splenic lymphocytes exhibited a significant increase in total T-cell count and CD4+/CD8 + ratio, while the LP lymphocytes (LPL) exhibited an increase in CD4+/CD8 + ratio only. They also exhibited a significant increase in porin-specific proliferative response and cytokine levels (IL-1, IL-2, IFN- $\gamma$ and IL-4). After immunisation, slgA antibody was also found to be increased. These results suggest that porins given intraperitoneally induce cellular and humoral immune responses both at systemic and mucosal levels.
\end{abstract}

\section{Introduction}

Typhoid fever is an important public health problem in many developing countries $[1,2]$. It has been estimated that the worldwide incidence of typhoid fever exceeds 12.5 million cases/year with a $1 \%$ mortality rate [3]. Typhoid fever is caused by Salmonella typhi, which replicates within the cells of the reticulo-endothelial system. The immune response to $S$. typhi infection is complex and involves cellular, secretory and serum components. In the mouse model, cellular components are involved in resistance to salmonella infection [46]. Similarly, it is believed that the cell-mediated immune (CMI) response to $S$. typhi in man plays a key role in defence against this infection.

The emergence of antibiotic multi-resistant Salmonella strains [7] and the high incidence of adverse reactions associated with traditional whole-cell killed vaccine have led to the development of a new generation of typhoid vaccines. Several attenuated $S$. typhi strains and subunit vaccines such as capsular polysaccharide (Vi) have been evaluated [8-12]. Presently, attention is focused on the role of porins in the induction of

Received 29 Jan. 1998; revised version accepted 22 April 1998.

Corresponding author: Dr N. K. Ganguly. specific immunity. It has been observed that porins induce both humoral and cellular immune responses [13-16]. For CMI response, an earlier study has shown elicitation of delayed-type hypersensitivity and lymphocyte proliferation with porins [15].

The present study aimed to investigate the ability of porins of $S$ typhi to modulate specific immune status both at systemic and mucosal levels in the host and the protection provided thereby. It also aimed to evaluate the porin-specific induction of lymphocyte transformation, $\mathrm{CD} 4+/ \mathrm{CD} 8+$ ratio, cytokine production and secretory $\operatorname{IgA}(\operatorname{sIg}$ ) in mice immunised with porins.

\section{Materials and methods}

\section{Bacterial strains}

S. typhi strain 0901 obtained from the Central Research Institute, Kasauli, HP, India, was used to prepare porins. S. typhi Ty2 (standard pathogenic strain) obtained from the same institute was used to challenge the mice.

\section{Animals}

Inbred BALB/c mice weighing $16-20 \mathrm{~g}$ were used for the experiments and also for isolation of thymocytes for interleukin-1 (IL-1) assay. All the mice were given sterile water and feed ad libitum throughout the experimentation. 


\section{Purification of porins}

Porins were purified from S. typhi strain 0901 by a modification of the method of Nikaido et al. [17]. Briefly, $S$. typhi cultured in L-broth containing Dglucose $0.5 \%$ at $37^{\circ} \mathrm{C}$ for $18 \mathrm{~h}$ was lysed with a French pressure cell. These lysed cells were treated for $30 \mathrm{~min}$ with sodium dodecyl sulphate (SDS) $2 \%$. After centrifugation at $100000 \mathrm{~g}$ for $30 \mathrm{~min}$, the pellet was treated for $2 \mathrm{~h}$ with $\mathrm{NaCl}$ buffer $(50 \mathrm{mM}$ Tris- $\mathrm{HCl}, \mathrm{pH}$ 7.7, $0.4 \mathrm{M} \mathrm{NaCl}$, SDS 1\%, $5 \mathrm{~mm}$ EDTA, mercaptoethanol $0.05 \%, 3 \mathrm{mM} \mathrm{NaN}$ ). After centrifugation at $100000 \mathrm{~g}$ for $30 \mathrm{~min}$ the supernate containing the crude porin was treated with trypsin $0.5 \mathrm{mg} / \mathrm{ml}$ at $37^{\circ} \mathrm{C}$ for $2 \mathrm{~h}$ and then passed through a Sephacryl S-200 column $(1.6 \times 86 \mathrm{~cm}$; Pharmacia $)$ pre-equilibrated with $\mathrm{NaCl}$ buffer. The fractions containing the porins were pooled and dialysed against $0.5 \mathrm{mM}$ Tris- $\mathrm{HCl}(\mathrm{pH} 7.4)$ for 8 days. For the characterisation of porins, SDSPAGE was performed as described previously [18]. The concentration of lipopolysaccharide (LPS) as a contaminant of porins was determined by Limulus amoebocyte lysate (LAL) assay [19].

\section{Protection study}

Protection against challenge was assessed as described previously [20]. Briefly, inbred BALB/c mice were divided into five groups of 10 . The mice in four groups were actively immunised with different concentrations of porins $(2.5,5.0,10$ or $20 \mu \mathrm{g})$ given intraperitoneally (i.p.) on days 0 and 14. The control group was given normal saline. At 7 days after the last immunisation, the mice were challenged with $300 \times$ LD50 of S. typhi Ty2. The numbers of deaths and survivors were recorded up to 15 days after challenge.

\section{Immunisation of mice}

For the study of other immunological parameters, four groups comprising 50 inbred BALB/c mice each were set up as detailed below. (1) Control group: $0.2 \mathrm{ml}$ of normal saline was injected i.p. into each mouse on days 0 and 14. (2) Infected group: mice were challenged i.p with $10^{3}$ organisms of $S$. typhi in $0.5 \mathrm{ml}$ of hog mucin. (3) Immunised group: mice in this group were immunised i.p. on days 0 and 14 with the minimum dose of porins $(10 \mu \mathrm{g})$ that provided maximum protection to mice against $300 \times$ LD50 of S. typhi. (4) Immunisedchallenge group: this group was first immunised as above and 7 days after the last immunisation injection, they were challenged with $300 \times$ LD50 of S. typhi Ty 2 in $0.5 \mathrm{ml}$ of hog mucin $5 \%$. The mice were killed 10 and 30 days after immunisation/challenge and various parameters were studied.

\section{Isolation of splenic cells}

Cells from the spleen were separated as described by Trizio and others [21]. Briefly, the spleen was removed aseptically and teased to separate the cells. The dispersed cells were filtered through a glass wool column and washed once in RPMI medium by centrifugation at $400 \mathrm{~g}$ for $10 \mathrm{~min}$. The red blood cells were lysed with chilled $\mathrm{NH}_{4} \mathrm{Cl} 0.9 \%$ solution and after centrifugation cells were suspended in tissue culture medium (RPMI-1640, Sigma, $2 \mathrm{mM} \mathrm{L-glutamine,}$ $20 \mathrm{mM}$ HEPES, streptomycin $100 \mathrm{U} / \mathrm{ml}, 5 \mathrm{mM} \beta$ mercaptoethanol (TCM) and fetal calf serum (FCS) $10 \%$ and incubated for $90 \mathrm{~min}$ in Petri plates. Both adherent (macrophages) and non-adherent (lymphocytes) cells were collected.

\section{Gut fluid collection}

The entire small intestine from the duodenum to the ileocaecal junction was removed and washed with $0.5 \mathrm{ml}$ of chilled phosphate-buffered saline (PBS). This fluid was centrifuged at $4000 \mathrm{~g}$ at $4^{\circ} \mathrm{C}$ for $5 \mathrm{~min}$. The supernate was collected, protease inhibitors were added and the material was stored at $-70^{\circ} \mathrm{C}$ until required.

\section{Isolation of lamina propria (LP) cells}

The cells were separated with some modifications of a protocol described previously [22]. The entire small intestine from duodenum to the ileocaecal junction was removed and washed with cold sterile normal saline. The Peyer's patches, blood vessels, fat and mesenteric tissues were completely removed. The intestine was first opened longitudinally and then cut laterally into small pieces $0.5 \mathrm{~cm}$ in length and washed extensively in Hanks's Balanced Salts Solution (HBSS). The pieces were treated three times for $30 \mathrm{~min}$ with HBSS containing $5 \mathrm{mM}$ EDTA at $37^{\circ} \mathrm{C}$ and transferred to $25 \mathrm{ml}$ of TCM containing FCS $5 \%$, DNAse $0.1 \mathrm{mg} / \mathrm{ml}$ and collagenase (type II) $0.15 \mathrm{mg} / \mathrm{ml}$. After incubation for $45 \mathrm{~min}$ at $37^{\circ} \mathrm{C}$ with slow stirring, the supernate was collected and the procedure was repeated once more. After the second washing the pieces were pumped through a syringe to effect total disruption. The dead cells and tissue debris were removed by passing the tissue suspension through a sterile glass wool column. The cell suspension was washed with TCM without FCS twice and incubated in a glass Petri plate at $37^{\circ} \mathrm{C}$ in air with $\mathrm{CO}_{2} 5 \%$ for $1.5 \mathrm{~h}$. The adherent cells were separated as macrophages and the non-adherent cell suspension was subjected to discontinuous gradient centrifugation to enrich for lymphocytes. The gradient was prepared by layering from the botttom $75 \%(2 \mathrm{ml})$ and $40 \%(2 \mathrm{ml})$ concentrations of Percoll. Approximately $(3-4) \times 10^{7}$ cells suspended in TCM with FCS $5 \%$ were loaded on the top of the Percoll $40 \%$ layer. After centrifugation at $600 \mathrm{~g}$ for $20 \mathrm{~min}$ at $20^{\circ} \mathrm{C}$ the layer formed at the interface to the $75 \%$ and $40 \%$ Percoll solutions was collected. This contained lymphocytes with $>90 \%$ viability. The yield was approximately $(7-8) \times 10^{6}$ cells $/$ mouse.

\section{Immunophenotyping of $T$ lymphocytes}

$\mathrm{T}$ cells isolated from spleen and LP were immunophenotyped as described previously [23]. Samples of 
$2 \times 10^{6}$ lymphocytes isolated from spleen or LP were incubated separately with $10 \mu \mathrm{l}$ of anti-CD3, anti-CD4 or anti-CD8 monoclonal antibodies (MAbs) labelled with either fluorescein isothiocyanate (FITC) or phycoerythrin (PE) for $30 \mathrm{~min}$ at room temperature in the dark. The cells were then washed with $2 \mathrm{ml}$ of PBS and fixed in $0.5 \mathrm{ml}$ of fixative (paraformaldehyde $0.05 \%$ ). The cells were identified on CELL QUEST software of FACScan (Becton Dickinson).

\section{Lymphocyte transformation}

Splenic lymphocytes were suspended in TCM and $2 \times 10^{6}$ cells $/ \mathrm{ml}$ were cultured with porins $20 \mu \mathrm{g}$ or concanavalin A (ConA) $5 \mu \mathrm{g} / \mathrm{ml}$ for $72 \mathrm{~h}$ at $37^{\circ} \mathrm{C}$ in air with $\mathrm{CO}_{2} 5 \% ; 6 \mathrm{~h}$ before the completion of the $72-\mathrm{h}$ period, tritiated thymidine $\left({ }^{3} \mathrm{H}\right)$ was added. After $72 \mathrm{~h}$, the cells were harvested and radioactivity was measured on a $\beta$-counter (LKB, Sweden). The results were expressed as cpm.

\section{Cytokine assay}

$I L-I$ production and measurement. This was done according to the method of Blydan et al. [24]. Briefly, $2 \times 10^{6}$ splenic or LP macrophages $/ \mathrm{ml}$ were cultured with $20 \mu \mathrm{g}$ of porins or $10 \mu \mathrm{g}$ of LPS at $37^{\circ} \mathrm{C}$ in air with $\mathrm{CO}_{2} 5 \%$ for $24 \mathrm{~h}$. After centrifugation, the supernate was collected and used for IL-1 assay. Volumes of $100 \mu \mathrm{l}$ of thymocytes $\left(2 \times 10^{7}\right.$ cells $\left./ \mathrm{ml}\right)$ from 4-6-week-old BALB/c mice were cultured with $100 \mu \mathrm{l}$ of serially two-fold diluted culture supernates and $20 \mu \mathrm{l}$ of PHA $(5 \mu \mathrm{g})$ in 96-well culture plates (Nunc). Six h before the completion of the 72-h incubation period, $0.5 \mu \mathrm{Ci}$ of tritiated thymidine was added. After $72 \mathrm{~h}$, the cells were harvested and radioactive counts were measured on a $\beta$-counter. The results were expressed as stimulation index derived from:

${ }^{3} \mathrm{H}$-thymidine incorporated by stimulated thymocytes cpm ${ }^{3} \mathrm{H}$-thymidine incorporated by unstimulated thymocytes $\mathrm{cpm}$

Il-2, IFN- $\gamma$ and $I L-4$ production and measurement. This was done according to the method of Hudson and Hay [25]. Briefly, splenic or LP lymphocytes (LPL) $2 \times 10^{6} / \mathrm{ml}$ were cultured with $20 \mu \mathrm{g}$ of porins at $37^{\circ} \mathrm{C}$ in air with $\mathrm{CO}_{2} 5 \%$ for $48 \mathrm{~h}$. The test included a standard challenge with ConA $10 \mu \mathrm{g}$. After $48 \mathrm{~h}$, the culture was centrifuged and the supernate was collected for cytokine assays.

IL-2 and IL-4 assays were done with the HT2 cell line. For IL-2 assay, HT2 cells were incubated with anti-IL-4 MAbs and for IL-4 assay, the cells were incubated with anti-IL-2 and -IL-2R MAbs (a cocktail of TIB 222, HB 8794 and CRC-1698). Then $100 \mu 1$ of $1 \times 10^{6} \mathrm{HT} 2$ cells $/ \mathrm{ml}$ were added into $100 \mu \mathrm{l}$ of supernate of lymphocyte culture taken in duplicate wells of a culture plate (Costar). For the negative control, instead of supernate, $100 \mu \mathrm{l}$ of TCM was added; $0.5 \mu \mathrm{Ci}$ of tritiated thymidine was added to each well $6 \mathrm{~h}$ before the completion of a 24-h incubation period at $37^{\circ} \mathrm{C}$ in air with $\mathrm{CO}_{2} 5 \%$. The cells were then harvested and the radioactive counts were measured with a $\beta$-counter. The results were expressed as $\mathrm{pg} / \mathrm{ml}$. The IFN- $\gamma$ assay was done similarly on the WEHI-279 cell line.

\section{Measurement of secretory $\operatorname{Ig} A$ response in intestinal fluid}

Anti-porin $\operatorname{sIgA}$ in intestinal fluid was measured by ELISA as described previously [26]. Briefly, $100 \mu \mathrm{l}$ of intestinal fluid diluted 1 in 256 in bovine serum albumin (BSA)-phosphate-buffered saline (PBS) were added to duplicate wells of a 9-well microtitration plate (Nunc) coated with $100 \mu \mathrm{l}$ of porins $(5 \mu \mathrm{g} / \mathrm{ml})$ and blocked with BSA $0.05 \% \mathrm{w} / \mathrm{v}$ in PBS. The plate was incubated at $37^{\circ} \mathrm{C}$ for $2 \mathrm{~h}$. After washing with PBSTween 20, anti-mouse IgA horseradish peroxidase conjugate was added and the plate was incubated at $37^{\circ} \mathrm{C}$ for $2 \mathrm{~h}$. The plate was then washed and $o$ phenylenediamine was added as substrate. The reaction was stopped after $30 \mathrm{~min}$ with $1 \mathrm{~N} \mathrm{H}_{2} \mathrm{SO}_{4}$ and the plate was read in an ELISA reader at $492 \mathrm{~nm}$.

\section{Statistics}

Data were analysed for statistical significance by an unpaired Student's $t$ test and results were considered to be significant at $\mathrm{p}<0.05$.

\section{Results}

Porins from $S$. typhi were purified by gel filtration chromatography and the peak obtained after $68 \mathrm{ml}$ contained pure porins. These were in trimer form and under reducing conditions they showed three bands of mol.wt 34,35 and $36 \mathrm{kDa}$ as described previously [27]. The results of LAL assay showed LPS contamination to be $0.02 \%$ in purified porins.

\section{Protection study}

When mice immunised with different concentrations of porins were challenged with $300 \times$ LD50 of $S$. typhi Ty2 in hog mucin $5 \%$, maximum protection was observed with $20 \mu \mathrm{g}$ of porins injected i.p in two equal doses. Subsequently, this dose of porins was used as the immunisation dose in BALB/c mice.

\section{Phenotypic characterisation of $T$ lymphocytes}

$\mathrm{T}$ lymphocytes isolated on days 5, 1020 and 30 from spleen and LP of control, infected, porin immunised and porin immunised-challenge groups were immunophenotyped. The total $\mathrm{T}$ cell counts and $\mathrm{CD} 4+/ \mathrm{CD} 8+$ ratio of splenic $\mathrm{T}$ cells are 
depicted in Fig. 1. The total T-cell count in the immunised and immunised-challenge groups was significantly increased as compared with the control group $(\mathrm{p}<0.001)$ throughout the study period except on day 5 in the immunised group. In the infected group, the total T-cell count was increased significantly on day 10 and significantly decreased on day 30. An increase in $\mathrm{CD} 4+/ \mathrm{CD} 8+$ ratio was observed in both immunised and immunised-challenge groups as compared with the control group and this increase remained significant on days 5, 10 and 20 of the study period in the infected group. The increase in $\mathrm{CD} 4+/ \mathrm{CD} 8+$ ratio on days 5 and 10 in the immunised group and on days 5, 10 and 20 in the immunised-challenge group was also significant as compared with the infected group.

As shown in Fig. 2a there was no significant change in total T-cell count from the LP among the study groups throughout the study period. The $\mathrm{CD} 4+/$ $\mathrm{CD} 8+$ ratio of $\mathrm{T}$ lymphocytes (Fig. 2b) isolated from LP of immunised and immunised-challenge groups was significantly increased as compared with the control group on days 5 and 10 . In the infected group this ratio was significantly increased as compared with the control group on day 5 only.
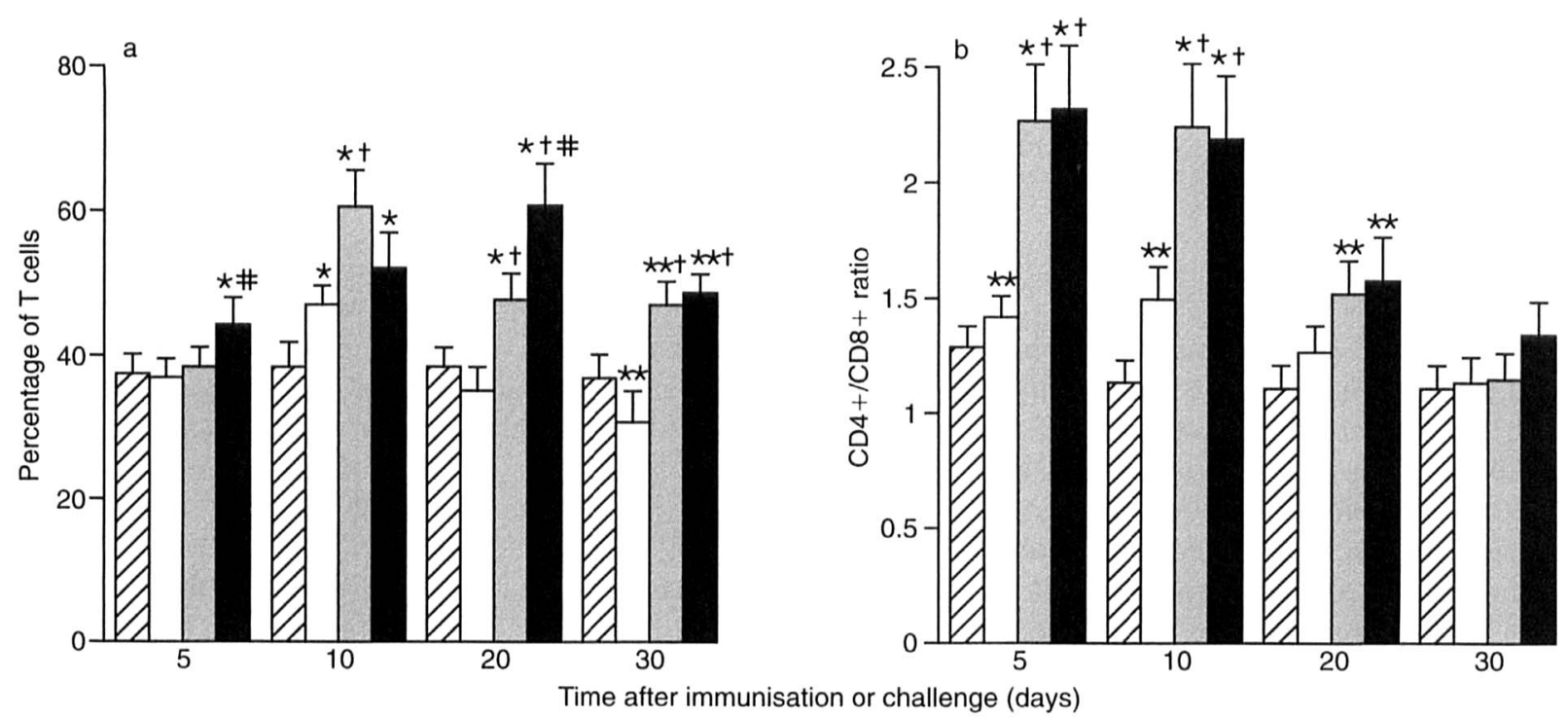

Fig. 1. Phenotypic characterisation of splenic T cells. (a) Total T cells; (b) ratio of CD4+/CD8+ cells. The values are mean and SD of four separate experiments. $\square$ Control group; $\square$ infected group; 圈 porin immunised group; $\square$ porin immunised-challenge group. ${ }^{*} \mathrm{p}<0.01$ as compared with control group; ${ }^{*} \mathrm{p}<0.05$ as compared with control group; $+\mathrm{p}<0.01$ as compared with infected group; $++\mathrm{p}<0.05$ as compared with infected group; \# $<<0.01$ as compared with immunised group.

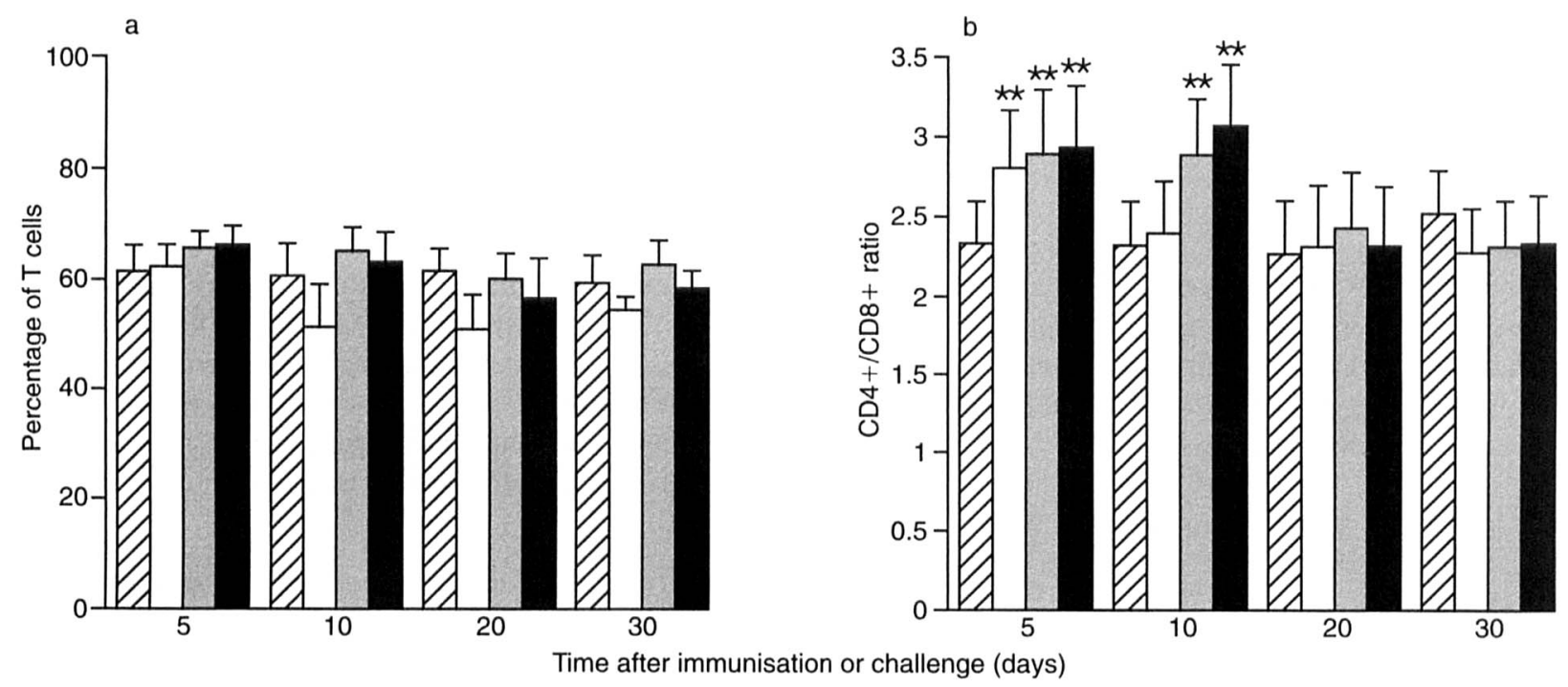

Fig. 2. Phenotypic characterisation of lamina propria $\mathrm{T}$ cells. (a) Total $\mathrm{T}$ cells; (b) ratio of $\mathrm{CD} 4+/ \mathrm{CD} 8+$ cells. The values are mean and SD of four separate experiments. $\square$ Control group; $\square$ infected group; 图 porin immunised group; porin immunised-challenge group. ${ }^{* *} \mathrm{p}<0.05$ as compared with control group. 


\section{Lymphocyte proliferation}

As shown in Table 1, there was a significant $(\mathrm{p}<0.01)$ increase in porin-induced proliferative response of lymphocytes isolated from the spleens of the immunised group as compared with the control group.

\section{Cytokine production}

Porins induced IL-1, IL-2, IFN- $\gamma$ and IL-4 production by splenic and LP cells isolated on days 5, 10, 20 and 30 from the control, infected, immunised and immunised-challenge groups.

IL-1 production. Fig. 3a shows the results of porininduced IL-1 production by splenic macrophages. In the infected, immunised and immunised-challenge groups, IL-1 production on days 5 and 10 was significantly increased $(p<0.01)$ as compared with the control group. This increase in the immunised and immunised-challenge groups was also significant $(\mathrm{p}<0.01)$ when compared with the infected group. As shown in Fig. 3b there was no significant increase in IL-1 production by macrophages isolated from the LP of infected, immunised and immunised- challenge groups as compared with that of the control group throughout the study period, except on day 5 .

$I L-2$ production. The values for IL-2 production are shown in Fig. 4a. Il-2 production on days 5, 10 and 20 was significantly increased in the infected group $(p<0.01)$ as compared with the control group. There was a significant increase in IL-2 production in the immunised and immunised-challenge groups as compared with the control group througout the study period. In these groups the increase on days 5,10 and 20 was also significant $(\mathrm{p}<0.01)$ as compared with the infected group. With ConA, IL-2 production by splenic lymphocytes isolated on day 10 from control, infected, immunised and immunised-challenge groups was 3025 SD 253.2, 950.6 SD 83, 1237 SD 125 and 1213 SD $112.4 \mathrm{pg} / \mathrm{ml}$, respectively.

As shown in Fig. 4b, there was a significant increase in IL-2 production in the porin-stimulated culture of LPL isolated from immunised and immunised-challenge groups on days 5, 10 and 20 as compared with the control group. The increase in IL-2 production in

Table 1. Lymphocyte stimulation with porins

\begin{tabular}{lcc}
\hline & \multicolumn{2}{c}{ Mean (SD) cpm in } \\
\cline { 2 - 3 } Treatment & Control group & Porin immunised group \\
\hline Unstimulated & $1286( \pm 207)$ & $1353( \pm 200)$ \\
Stimulated with porins $(20 \mu \mathrm{g} / \mathrm{ml})$ & $4341( \pm 628)$ & $* 58255(8340)$ \\
Non-specific stimulation $($ ConA $5 \mu \mathrm{g} / \mathrm{ml})$ & $95720( \pm 15393)$ & $68739( \pm 12008)$ \\
\hline
\end{tabular}

Results ae expressed as mean ( $\pm \mathrm{SD})$ of four separate experiments

${ }^{*} \mathrm{p}<0.01$ as compared with control group.

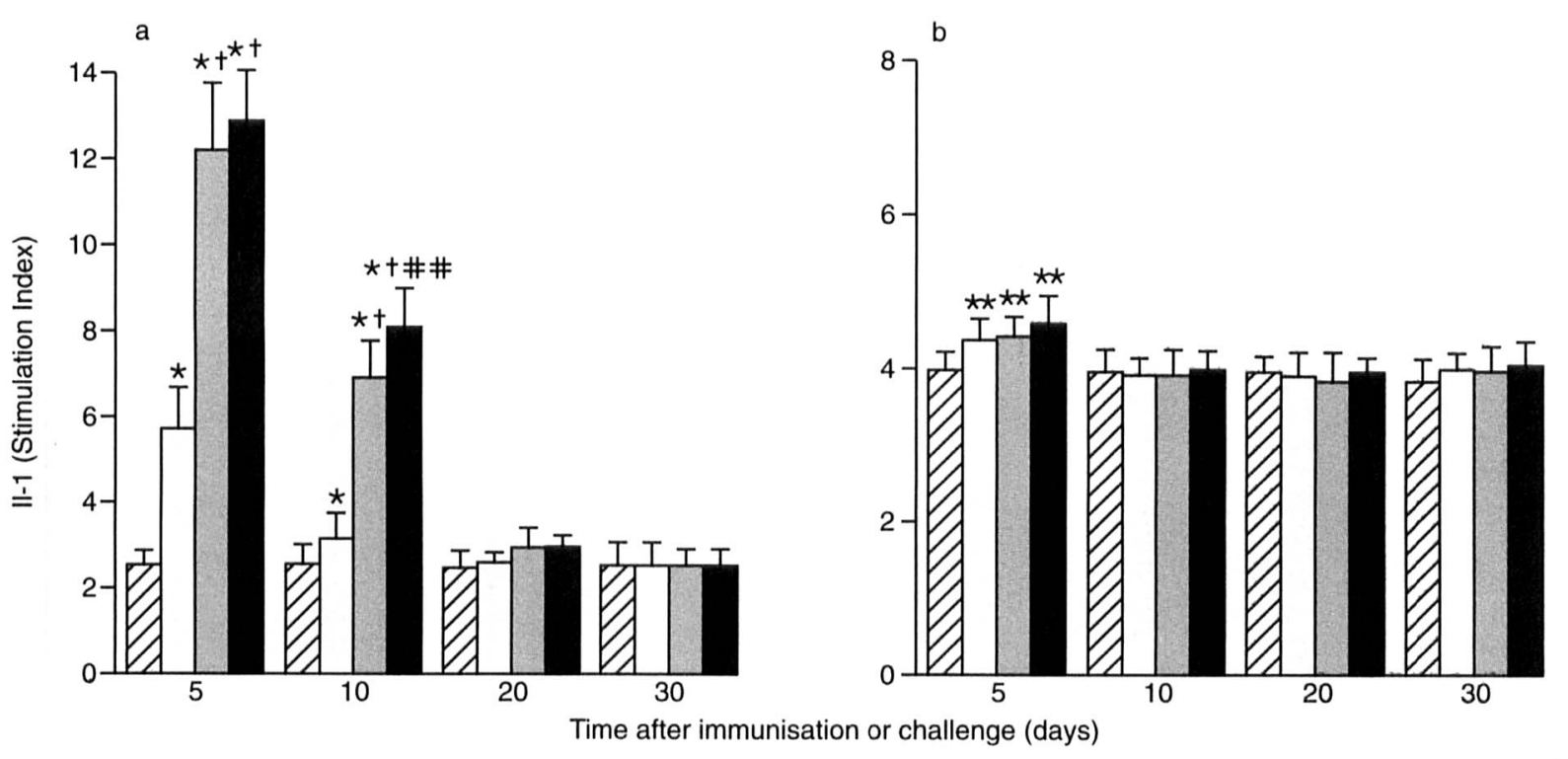

Fig. 3. IL-1 production in cultures of (a) splenic macrophages and (b) lamina propria macrophages stimulated with porins. The values are mean and SD of six and four separate experiments with splenic and lamina propria macrophages respectively. $\square$ Control group; $\square$ infected group; 圈 porin immunised group; $\square$ porin immunised-challenge group. ${ }^{*} \mathrm{p}<0.01$ as compared with control group; ${ }^{* *} \mathrm{p}<0.05$ as compared with control group; $+\mathrm{p}<0.01$ as compared with infected group; \# $<0.01$ as compared with immunised group. 


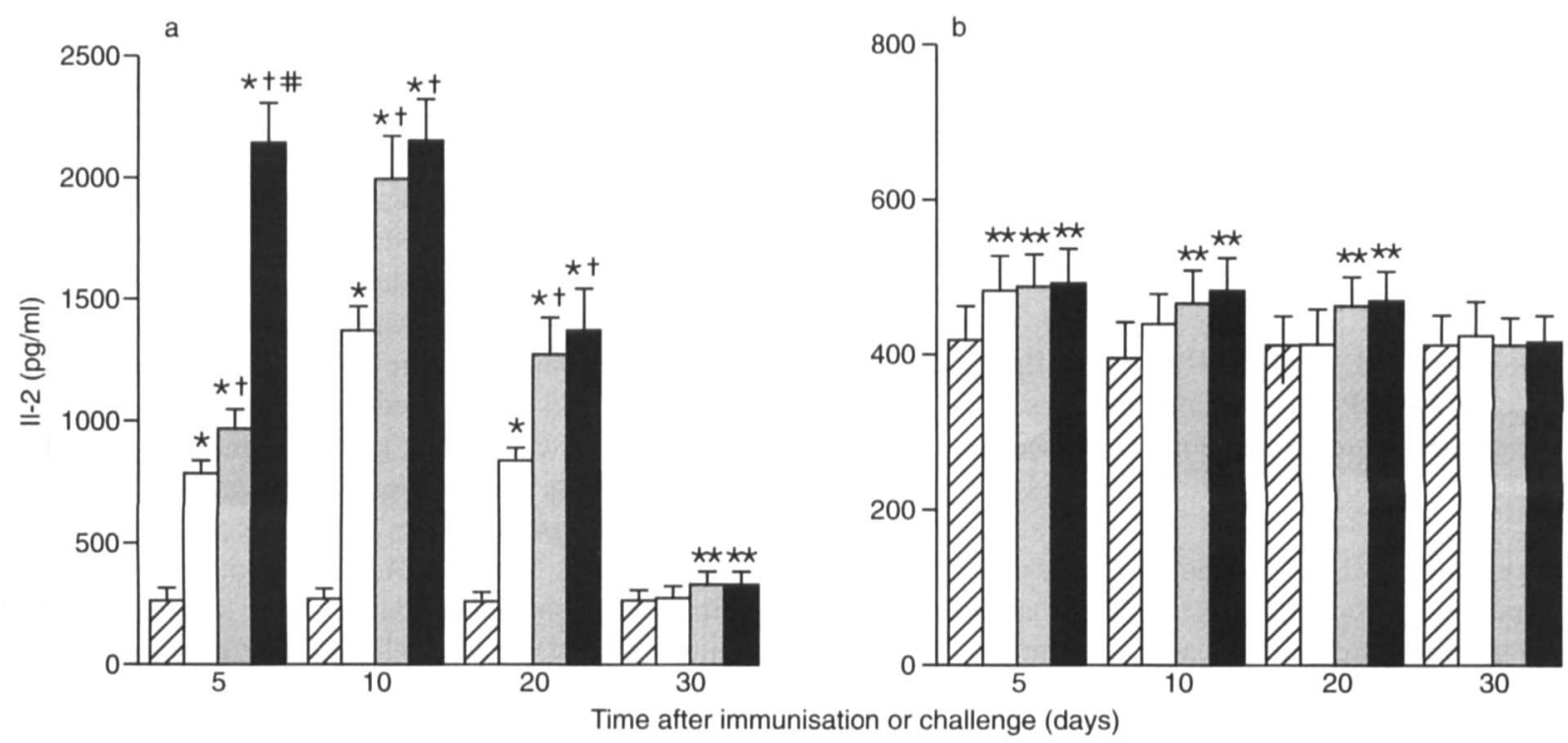

Fig. 4. IL-2 production in cultures of (a) splenic lymphocytes and (b) lamina propria lymphocytes stimulated with porins. The values are mean and SD of six and four separate experiments with splenic and lamina propria lymphocytes respectively. $\nabla_{i}$ Control group; $\square$ infected group; 0 porin immunised group; $\square$ porin immunised-challenge group. ${ }^{*} \mathrm{p}<0.01$ as compared with control group; ${ }^{* *} \mathrm{p}<0.05$ as compared with control group; $+\mathrm{p}<0.01$ as compared with control group.

the porin-stimulated culture of LPL isolated from the infected group was significant as compared with the control group on day 5 . With ConA, IL-2 production in cultures of LPL isolated on day 10 from control, infected, immunised and immunised-challenge groups was 2270 SD $239.8,1134$ SD 133.3, 1074 SD 87.45 and $1082 \mathrm{SD} 107.5 \mathrm{pg} / \mathrm{ml}$, respectively.

IFN- $\gamma$ production. As for IL- 2 production, IFN- $\gamma$ was significantly increased in the infected, immunised and immunised-challenge groups as compared with the control group throughout the study (Fig. 5a). This increase in the immunised-challenge group was also significant as compared with the infected group throughout the study period. Similarly, the increase in IFN- $\gamma$ production on days 20 and 30 in the immunised group was also significant as compared with the infected group. Lymphocytes isolated on day 10 from control, infected, immunised and immunised-challenge groups, upon stimulation with ConA $(10 \mu \mathrm{g} / \mathrm{ml})$

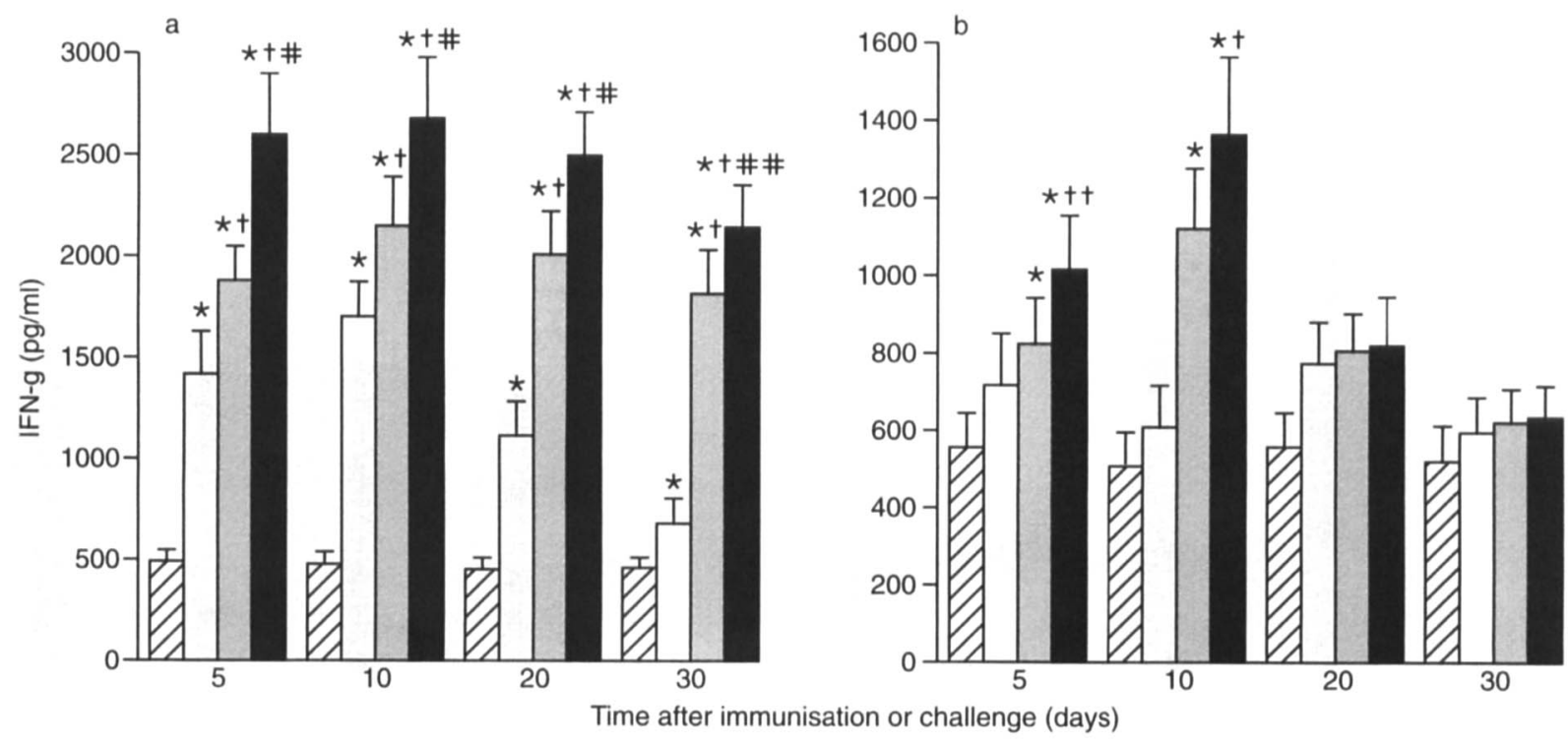

Fig. 5. IFN- $\gamma$ production in cultures of (a) splenic lymphocytes and (b) lamina propria lymphocytes stimulated with porins. The values are mean and SD of six and four separate experiments with splenic and lamina propria lymphocytes respectively. $\square$ Control group; $\square$ infected group; a porin immunised group; $\mathbf{\square}$ porin immunised-challenge group. ${ }^{*} \mathrm{p}<0.01$ as compared with control group; $+\mathrm{p}<0.01$ as compared with infected group; $++\mathrm{p}<0.05$ as compared with infected group; \#p $<0.01$ as compared with immunised group; \# \# $<0.05$ as compared with immunised group. 
released 1404 SD 170, 781 SD 90, 1227 SD 158 and 1085 SD $152 \mathrm{pg}$ of IFN $-\gamma / \mathrm{ml}$, respectively.

The IFN- $\gamma$ production by LPL isolated from immunised and immunised-challenge groups was also increased significantly on days 5,10 and 20 as compared with the control group (Fig. 5b). Lymphocytes isolated on day 10 from LP of control, infected, immunised and immunised-challenge groups on incubation with ConA $(10 \mu \mathrm{g} / \mathrm{ml})$ released 1531 SD 168, 1174 SD 143, 1511 SD 172 and 1509 SD 188 pg of IFN- $\gamma / \mathrm{ml}$, respectively.

IL-4 production. Fig. 6a shows IL-4 production elicited by porins in cultures of splenic lymphocytes. Although IL-4 production in the infected, immunised and immunised-challenge groups was significantly increased as compared with the control group on days 5 and 10 of the study period, this was lower in comparison with porin-induced IL-2 and IFN- $\gamma$ production (Figs. 4 and 5). With ConA, IL-4 production in cultures of splenic lymphocytes isolated on the day 10 from control, infected, immunised and immunised-challenge groups was 160 SD 23.9, 142.7 SD 17, 128.7 SD 19.52 and 164 SD $22.5 \mathrm{pg}$ of IL-4/ml, respectively.

The investigation of IL-4 production by LPL showed that there was no significant increase in IL-4 production by LPL isolated from infected, immunised and immunised-challenge groups as compared with the control group throughout the study period, except on day 5 in immunised and immunised-challenge groups (Fig. 6b). With ConA, Il-4 production in cultures of
LPL isolated from control, infected, immunised and immunised-challenge groups was 79.2 SD 9.6, 71.5 SD 12.3, 83.3 SD 13.5 and 104.7 SD $19.0 \mathrm{pg} / \mathrm{ml}$, respectively.

\section{Secretory IgA response in intestinal fluid}

Fig. 7 shows the sIgA antibody response in intestinal fluid. It was observed that there was a significant increase in $\operatorname{sgA}$ antibody in the immunised and immunised-challenge groups as compared with the control group on days 5 and 10 . By days 20 and 30 , the sIgA antibody level had decreased to the control level. In the infected group there was no signifiant increase in sIgA level. Intestinal fluid collected from mice orally infected with $1 \times 10^{6}$ cells of $S$. typhimurium was used as positive control.

\section{Discussion}

This study investigated the specific systemic and mucosal cellular immune responses to porins of $S$. typhi along with the mucosal humoral immune response. Phenotypic change, proliferation and cytokine production were studied with splenic and LP cells isolated from infected, porin immunised and immunised-challenge groups along with the control group. SIgA antibody response was also measured to study the mucosal immune response. The porins purified from $S$. typhi strain 0901 contained little LPS contamination $(0.02 \%)$. Earlier studies showed that this amount of LPS contamination does not influence the immune response [13]. The porins provided $90 \%$ protection

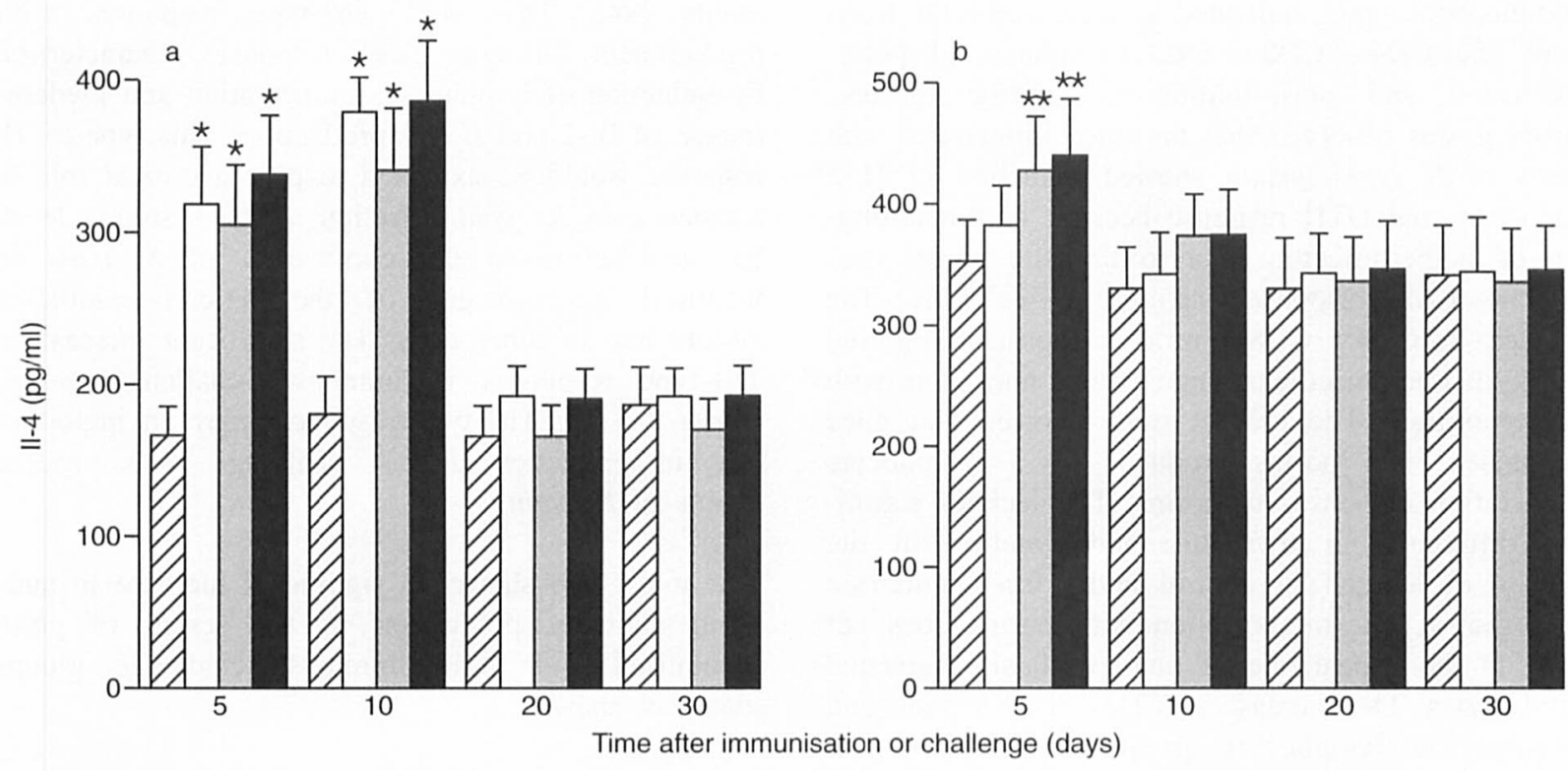

Fig. 6. IL-4 production in cultures of (a) splenic lymphocytes and (b) lamina propria lymphocytes stimulated with porins. The values are mean and SD of six and four separate experiments with splenic and lamina propria lymphocytes respectively. Control group; $\square$ infected group; $\square$ porin immunised group; $\square$ porin immunised-challenge group. ${ }^{*} \mathrm{p}<0.01$ as compared with control group; ${ }^{* *} \mathrm{p}<0.05$ as compared with control group. 


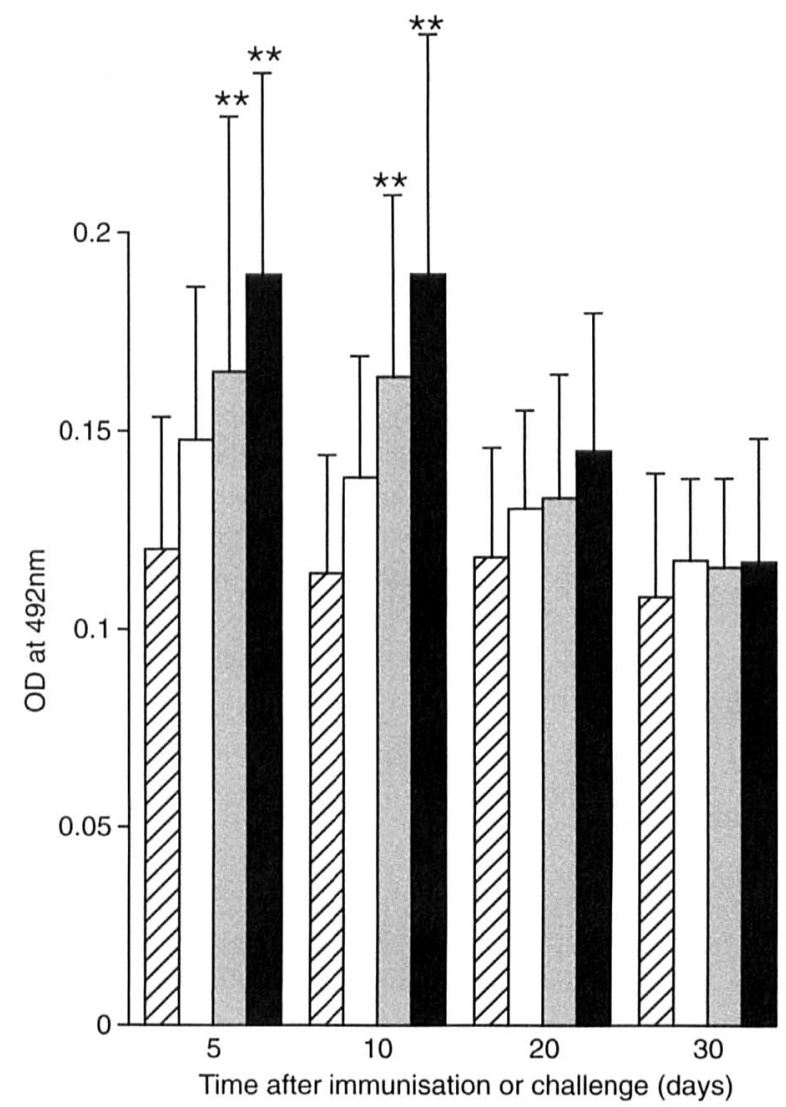

Fig. 7. Anti-porin secretory $\operatorname{IgA}$ response in intestinal fluid. The values are mean and SD of six separate experiments. Control group; $\square$ infected group; $\square$ porin immunised group; $\square$ porin immunised-challenge group. ${ }^{* *} \mathrm{p}<0.05$ as compared with control group.

against $300 \times \mathrm{LD} 50$ of $S$. typhi Ty2, in BALB/c mice, confirming earlier results [28].

Immunophenotyping indicated an increased total T-cell count and $\mathrm{CD} 4+/ \mathrm{CD} 8+$ ratio in spleens of porinimmunised and porin-immunised-challenge groups. Earlier it was observed that the mice immunised with porins of $S$. typhimurium showed induction of IL-2 production and DTH response because of the infiltration of helper-effector cells to the site where they generate CMI responses against porins [16]. The increase in $\mathrm{CD} 4+/ \mathrm{CD} 8+$ ratio in porin immunised and porin immunised-challenge groups may fit in with this hypothesis. The present study showed that mice immunised with porins produced good lymphocyte proliferation responses to porins. The lack of significant difference in thymidine incorporation in the absence of antigen in control and porin immunised mice shows that immunisation with porins does not result in the appearance of non-specifically activated lymphocytes. The increase in $\mathrm{CD} 4+/ \mathrm{CD} 8+$ ratio and porin-specific lymphocyte proliferation shows that porins induce a CMI response.

Previously it has been observed that the pro-inflammatory effects of porins, functioning as chemo- attractants, cause the release of histamine from rat peritoneal cells and induce rat paw oedema [29]. IL-1 production in the present study was significantly increased in the porin immunised and porin immunised-challenge groups as compared with the control group. A significantly high chemiluminescence response to porins has been observed in the monocytes of typhoid patients (unpublished data). This finding, as well as the production of IL-1 seen in the present study, may mean that monocytes/macrophages in blood and spleen are activated by porins. IL-1 has several pro-inflammatory effects, which include activation of $\mathrm{T}$ cells and polymorphonuclear leucocytes neutrophil and induction of monokine production (including IL-6 or IL-8).

Studies in mice and man have shown that, on the basis of reciprocal cytokine secretion patterns, Thelper (Th) lymphocytes can be divided into subpopulations termed Thl (characterised by the production of IL- 2 and IFN- $\gamma$ ), Th2 (characterised by the production of IL-4, IL-5, IL-6, IL-10 and IL-13) and Th0 (these secrete cytokines that do not fall into the Th1 and Th2 patterns) [30-32]. In general Th1 cells mediate CMI, provide B-cell help and activate macrophages to kill intracellular pathogens, whereas Th2 cells predominantly provide help to B cells for antibody production. IFN- $\gamma$ involved in resistance to intracellular bacteria plays an important role in the defence against salmonella infection, probably by augmenting macrophage bactericidal activity [33].

The present study found that production of IL-2, IFN$\gamma$ and IL-4 was increased in infected, porin immunised and porin immunised-challenge mice, and that production of IL-2 and IFN- $\gamma$ was greater than that of IL-4. The results suggest that immunisation with porins elicits both Th1- and Th2-type responses with predominant Th1-type T-cell responses, characterised by induction of lymphocyte proliferation and predominance of IL-2 and IFN- $\gamma$ production. This type of Th response would be expected to play a critical role in resistance to $S$. typhi infection at the systemic level, by contributing to the elimination of $S$. typhi in localised macrophages of the reticulo-endothelial system and in other cells. The significant increase in Thl-type responses in immunised-challenge groups shows that the Th1-type responses play an important role in protection against challenge with virulent strains of $S$. typhi.

The study also showed a significant increase in antiporin antibody production in the serum of porin immunised and porin immunised-challenge groups (data not shown).

As $S$. typhi enters the host through the gut and as studies with several bacterial pathogens have shown that local antibodies secreted on to a mucosal surface can prevent colonisation and subsequent disease [34- 
36], it may be desirable to induce a local immune response against $S$. typhi. The present study investigated whether immunisation of mice with porins induced a mucosal immune response. The $\operatorname{sIgA}$ antibody response, immunophenotyping of $\mathrm{T}$ cells and cytokine production by LP cells were examined. The significant increase in SIgA antibody level, $\mathrm{CD} 4+/ \mathrm{CD} 8+$ ratio and cytokine production (IL-1, IL-2, IFN- $\gamma$ and IL-4) in porin immunised and porin immunised-challenge groups showed that porins, when given i.p., also induced mucosal immune response. Previous studies with cholera toxin have indicated that a site-restricted $\operatorname{sIg} A$ response and other mucosal responses can be induced only by the local application of antigen to the mucosal surface and cannot be induced by giving the antigen intravenously $[37,38]$.

Thus it can be concluded that porins are good immunogens, which, when given intraperitoneally, are able to induce both cellular and humoral immune responses at both systemic and mucosal levels. In a separate experiment it was observed that when porin immunised animals were challenged with $S$. typhi, the organisms could be cultured from the spleen and peritoneal cavity for up to 7 days, but not afterwards (data not shown) so the immunity was not sterile. Therefore, porins can protect mice against $S$. typhi, possibly through both cellular and humoral immune responses induced systemically and locally. If this is also true in the human situation, then porins may act as good immunogens against typhoid fever.

\section{References}

1. Edelman R, Levine MM. Summary of an international workshop on typhoid fever. Rev Infect Dis 1986; 8: 329-349.

2. Thisyakon U, Mansuwan P, Taylor DN. Typhoid and paratyphoid fever in 192 hospitalized children in Thailand. $A m J$ Dis Child 1987; 141: 862-865.

3. Calva E, Puente JL, Calva JJ. Research opportunities in typhoid fever; epidemiology and molecular biology. Bioessays 1988; 9: $173-177$.

4. Killar LM, Eisenstein TK. Immunity to Salmonella typhimurium infection in $\mathrm{C} 3 \mathrm{H} / \mathrm{HeJ}$ and $\mathrm{C} 3 \mathrm{H} / \mathrm{HeNCrlBR}$ mice: studies with an aromatic-dependent live $S$. typhimurium strains as a vaccine. Infect Immun 1985; 47: 605-612.

5. Killar LM, Eisenstein TK. Differences in delayed-type hypersensitivity responses in various mouse strains in the C3H lineage infected with Salmonella typhimurium strain SL3235. J Immunol 1984; 133: 1190-1196.

6. Mastroeni P, Villarreal Ramos B, Hormaeche CE. Role of T cells, TNF- $\alpha$ and IFN- $\gamma$ in recall of immunity to oral challange with virulent salmonellae in mice vaccinated with live attenuated aro-Salmonella vaccines. Microb Pathog 1992; 13: $477-491$.

7. Gupta B, Kumar R, Khurana S. Multi drug resistant Salmonella typhi in Ludhiana(Punjab). Indian J Pathol Microbiol 1993; 36: 5-7.

8. Acharya IL, Lowe CU, Thapa R et al. Prevention of typhoid fever in Nepal with the Vi capsular polysaccharide of Salmonella typhi. $N$ Engl J Med 1987; 317: 1101-1104.

9. Klugman KP, Gibertson IT, Koornhof HJ et al. Protective activity of $\mathrm{Vi}$ capsular polysaccharide vaccine against typhoid fever. Lancet 1987; ii: 1165-1169.

10. Simanjuntak $\mathrm{CH}$, Paleologo FP, Punjabi NH et al. Oral immunisation against typhoid fever in Indonesia with Ty2la vaccine. Lancet 1991; 338: 1055-1059.

11. Wadhan $\mathrm{MH}$, Sere $\mathrm{C}$, Germanier $\mathrm{R}$ et al. A controlled field trial of live oral typhoid vaccine Ty21a. Bull World Health Organ 1980; 58: 469-474.

12. Wadhan MH, Sérié C, Cerisier Y, Sallam S, Germanier R. A controlled field trial of live Salmonella typhi strain Ty 21 a oral vaccine against typhoid. Three-year results. $J$ Infect Dis 1982; 145: $292-295$.

13. Calderón I, Lobos SR, Rojas HA, Palomino C, Rodríguez LH, Mora GC. Antibodies to porin antigens of Salmonella typhi induced during typhoid fever in humans. Infect Immun 1986; 52: $209-212$.

14. Galdiero F, Cipollaro De L'ero G, Benedetto N, Galdiero M, Tufano MA. Release of cytokines induced by Salmonella typhimurium porins, Infect Immun 1993; 61: 155-161.

15. Gonzalez CR, Isibasi A, Ortiz-Navarrete V et al. Lymphocytic proliferative response to outer-membrane proteins isolated from Salmonella. Microbiol Immunol 1993; 37: 793-799.

16. Matsui K, Arai T. Specificity of Salmonella porin as a eliciting antigen for cell-mediated immunity (CMI) reaction in murine salmonellosis. Microbiol Immunol 1989; 33: 1063-1067.

17. Nikaido $H$. Proteins forming large channels from bacterial and mitochondrial outer membranes: porins and phage lambda receptor protein. Methods Enzymol 1983; 97: 85-100.

18. Laemmli UK. Cleavage of structural proteins during the assembly of the head of bacteria phage T4. Nature 1970; 227: $680-685$.

19. Technical Bulletin. E-toxate (Limulus amoebocyte Lysate) for detection and semi quantitation of endotoxin. St Louis, Sigma Chemical Company. 1992: 210.

20. Kuusi N, Nurminen $M$, Saxen $H$, Vatttonen $M$, Mäkelä $P H$. Immunization with major outer membrane proteins in experimental salmonellosis of mice. Infect Immun 1979; 25: $857-862$.

21. Trizio D, Cudcowicz G. Separation of T and B lymphocytes by nylon wool columns: evaluation of efficacy by functional assays in vivo. J Immunol 1974; 113: 1093-1097.

22. Taguchi T, McGhee JR, Coffman RL et al. Analysis of Th1 and $\mathrm{Th} 2$ cells in murine gut-associated tissues. Frequencies of CD4+ and CD8+ $\mathrm{T}$ cells that secrete IFN- $\gamma$ and IL-5. $J$ Immunol 1990; 145: 68-77.

23. Hayakanea K, Handy RR. Murine CD4+ T cell subsets. Immunol Rev 1991; 123: 145-168.

24. Blyden G, Handschumacher RE. Purification and properties of human lymphocyte activating factor (LAF). J Immunol 1977; 118: $1631-1638$.

25. Hudson L, Hay FC. Practical immunology, 2nd edn. Oxford, Blackwell Scientific Publication. 1980.

26. Bartholomeusz RCA, Forrest BD, Labrooy JT et al. The serum polymeric IgA antibody response to typhoid vaccination: its relationship to the intestinal IgA response. Immunology 1990; 69: $190-194$.

27. Tabaraie B, Sharma BK, Sharma PR, Sehgal R, Ganguly NK. Evaluation of Salmonella porins as a broad spectrum vaccine candidate. Microbiol Immunol 1994; 38: 553-559.

28. Sharma P, Ganguly NK, Sharma BK, Sharma S, Sehgal R. Specific immunoglobulin response in mice immunized with porins and challenged with Salmonella typhi. Microbiol Immunol 1989; 33: 519-525.

29. Galdiero F, Tufano MA, Galdiero M, Masiello S, Di Rosa M. Inflammatory effects of Salmonella typhimurium porins. Infect Immun 1990; 58: 3183-3186.

30. King CL, Nutman TB. IgE and IgG subclass regulation by IL-4 and IFN- $\gamma$ in human helminth infections. Assessment by B cell precursor frequencies. $J$ Immunol 1993; 151: 458-465.

31. Parronchi P, De Carli M, Manetti R et al. Il-4 and IFN ( $\alpha$ and $\gamma$ ) exert opposite regulatory effects on the development of cytolytic potential by $\mathrm{Th} 1$ or Th2 human $\mathrm{T}$ cell clones. J Immunol 1992; 149: 2977-2983.

32. Romagnani S. Lymphokine production by human $T$ cells in disease states. Annu Rev Immunol 1994; 12: 227-257.

33. Kauffmann SHE, Munk ME, Koga $\mathrm{T}$ et al. Effector $\mathrm{T}$ cells in bacterial infections. In: Melchers F, Albert ED, von Boehmer $\mathrm{H}$ et al. (eds) Progress in Immunology VII. Berlin, SpringerVerlag. 1989: 963-970.

34. Cantey JR. Prevention of bacterial infections of mucosal surfaces by immune secretory IgA. Adv exp Med Biol 1978; 107: $461-470$. 
88 SINGH ET AL.

35. Fubara ES, Freter R. Protection against enteric bacterial infection by secretory IgA antibodies. J Immunol 1973; 111: 395-400.

36. Williams RC, Gibbons RJ. Inhibition of bacterial adherence by secretory immunoglobulin A: a mechanism of antigen disposal. Science 1972; 177: 697-699.
37. Pierce NF, Gowans JL. Cellular kinetics of the intestinal immune response to cholera toxoid in rats. J Exp Med 1975; 142: $1550-1563$.

38. Svennerholm AM, Sack DA, Holmgren J, Bardhan PK. Intestinal antibody responses after immunisation with cholera B subunit. Lancet 1982; 1: 305-308. 